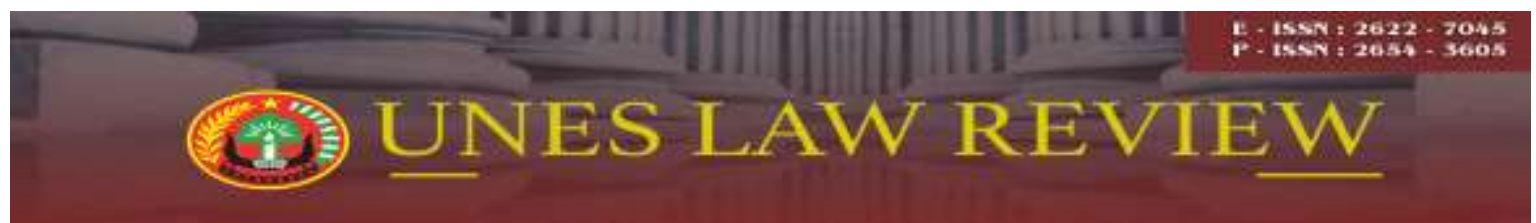

Email: uneslawreview@gmail.com

Online: http://review-unes.com/index.php/law

Volume 2, Issue 1, September 2019

\title{
PERTIMBANGAN HAKIM PADA PUTUSAN PRAPERADILAN NO. 97/PID.PRAP/2017/ PN.JKT.SEL DAN N0 04/PID.PRAP/2015/PN.JAK.SEL TENTANG PENETAPAN STATUS TERSANGKA
}

\author{
Dasrinal \\ Anggota POLRI, Kepolisian Daerah Sumatra Barat \\ E-mail : dasrinal@gmail.com
}

\begin{abstract}
Determination of suspect status is an extension of the pretrial object. The problem is the consideration of pretrial judges in deciding pretrial applications to determine the status of suspects in case No. 97 / PID.PRAP / 2017 / PN.JKT.SEL and case No. 04 / PID.PRAP / 2015 / PN.JAK.SEL. This research is legal research with analytical descriptive specifications with a normative juridical approach. Normative legal research approach. The results showed that the Judge's consideration of the pretrial request was the validity of the evidence used as the basis for determining the suspect. Another consideration is the object of pretrial requests not the authority of a pretrial judge. Pre-trial Judge's Decision Against Pretrial Request Determination of the Status of Suspects is in part granted the Pretrial Petitioner in part;
\end{abstract}

Kata Kunci: Praperadilan, Pertimbangan Hakim, Putusan Pengadilan, Tersangka

\section{PENDAHULUAN}

Praperadilan sendiri diatur dalam Undang-undang Nomor 8 Tahun 1981 tentang Hukum Acara Pidana (selanjutnya disebut KUHAP), khususnya Pasal 1 angka 10, Pasal 77 sampai dengan Pasal 83, Pasal 95 ayat (2) dan ayat (5), Pasal 97 ayat (3), dan Pasal 124. Adapun yang menjadi objek praperadilan sebagaimana yang diatur dalam Pasal 77 KUHAP adalah: "Pengadilan Negeri berwenang untuk memeriksa dan memutus, sesuai dengan ketentuan yang diatur dalam Undang-undang ini tentang:

1. Sah atau tidaknya penangkapan, penahanan, penghentian penyidikan atau penghentian penuntutan;

2. Ganti kerugian dan atau rehabilitasi bagi seorang yang perkara pidananya dihentikan pada tingkat penyidikan atau penuntutan."

Menurut ketentuan di atas bahwa lembaga praperadilan adalah lembaga untuk menguji mengenai sah tidaknya tindakan aparatur negara bidang penegakan hukum apabila melakukan tindakan hukum yang berupa penangkapan, penahanan, penghentian 
penyidikan dan penghentian penuntutan dan yang perlu diperhatikan dalam gugatan praperadilan ini adalah tentang sah tidaknya tindakan di atas di lakukan. Putusan Mahkamah Konstitusi Nomor 21/PUU-XII/2014, diputuskan bahwa ketentuan Pasal 77 huruf a KUHAP tidak memiliki kekuatan hukum mengikat sepanjang tidak dimaknai termasuk penetapan tersangka, penggeledahan dan penyitaan.

Adapun salah satu pertimbangan hukumnya, penetapan tersangka adalah bagian dari proses penyidikan yang merupakan perampasan terhadap hak asasi manusia maka seharusnya penetapan tersangka oleh penyidik merupakan objek yang dapat dimintakan perlindungan melalui ikhtiar hukum pranata praperadilan. Hal tersebut semata-mata untuk melindungi seseorang dari tindakan sewenang-wenang penyidik yang kemungkinan besar dapat terjadi ketika seseorang ditetapkan sebagai tersangka, padahal dalam prosesnya ternyata ada kekeliruan maka tidak ada pranata lain selain pranata praperadilan yang dapat memeriksa dan memutusnya (Riki Perdana Raya, 2018).

Polemik inibermula ketika Hakim Sarpin Rizaldi mengabulkan permohonan praperadilan Budi Gunawan di Pengadilan Negeri Jakarta Selatan. Saat itu, salah satu permohonan praperadilan yang diajukan dan diterima adalah mengenai sah tidaknya penetapan tersangka yang dilakukan KPK terhadap Budi Gunawan. Pengadilan Negeri Jakarta Selatan melalui lembaga praperadilan menerima hal tersebut dan menyatakan pada intinya bahwa penetapan tersangka adalah salah satu bentuk upaya paksa dan dapat diuji melalui praperadilan.

Berdasarkan latar belakang pemikiran yang telah dipaparkan di atas, maka rumusan permasalahan adalah Bagaimanakah pertimbangan hakim praperadilan pada permohonan praperadilan penetapan status tersangka pada perkara No. 97/PID.PRAP/2017/ PN.JKT.SEL dan perkara No. 04/PID.PRAP/2015/ PN.JAK.SEL dan Bagaimanakah putusan hakim praperadilan pada permohonan praperadilan penetapan status tersangka pada perkara No. 97/PID.PRAP/2017/ PN.JKT.SEL dan perkara No. 04/PID.PRAP/2015/ PN.JAK.SEL?

\section{METODE PENELITIAN}

Spesifikasi penelitian adalah deskriptif analisis, dengan metode pendekatan yuridis normatif. Jenis data yang digunakan adalah data sekunder. Data sekunder diperoleh dari 
studi dokumen dan studi kepustakaan. Teknik pengumpulan data pada data sekunder dilakukan dengan studi kepustakaan. Data yang diperoleh kemudian dianalisa secara kualitatif .

\section{PEMBAHASAN}

Pertimbangan Hakim Praperadilan Pada Permohonan Praperadilan Penetapan Status Tersangka Pada Perkara 97/Pid.Prap/2017/PN.Jkt.Sel. Dan Perkara No 04/Pid.Prap/2015/PN.Jak.Sel

Putusan Praperadilan Nomor: 97/Pid.Prap/2017/PN.Jkt.Sel. diajukan oleh Pemohon Setya Novanto melalui Tim Kuasa hukumnya, melawan Komisi Pemberantasan Korupsi (KPK) selaku Termohon, yang menetapkan Setya Novanto sebagai tersangka tindak pidana korupsi Pengadaan Paket Penerapan Kartu Tanda Penduduk Berbasis Nomor Induk Kependudukan Secara Nasional (KTP Elektronik) Tahun 2011 s/d 2012 pada Kementerian Dalam Negeri Republik Indonesia.

Pertimbangan hukum hakim dalam mengabulkan permohonan Praperadilan pada Putusan Praperadilan Nomor:97/Pid.Prap/2017/ PN.Jkt.Sel. adalah alat bukti yang dijadikan sebagai dasar penetapan tersangka, setelah dipelajari dan diteliti tidak disertai dengan berita acara penyitaan, yang tidak sesuai dengan Pasal 47 Undang-undang Nomor 30 Tahun 2002 tentang Komisi Pemberantasan Tindak Pidana Korupsi yang menyebutkan:

a. Atas dasar dugaan yang kuat adanya bukti permulaan yang cukup, penyidik dapat melakukan penyitaan tanpa izin Ketua Pengadilan Negeri berkaitan dengan tugas penyidikannya.

b. Ketentuan peraturan perUndang-undangan yang berlaku yang mengatur mengenai tindakan penyitaan, tidak berlaku berdasarkan Undang-undang ini.

c. Penyidikan sebagaimana dimaksud pada Ayat (1) wajib membuat berita acara penyitaan pada hari penyitaan yang sekurang-kurangnya memuat:

1) Nama, jenis, dan jumlah barang atau benda berharga lain yang disita.

2) Keterangan tempat, waktu, hari, tanggal, bulan, dan tahun dilakukannya penyitaan.

3) Keterangan mengenai pemilik atau yang menguasai barang atau benda berharga lain tersebut.

4) Tanda tangan dan identitas penyidk yang melakukan penyitaan, dan,

5) Tanda tangan dan identitas dari pemilik atau orang yang menguasai barang tersebut 
d. Salinan berita acara penyitaan sebagaimana dimaksud pada Ayat (3) disampaikan kepada tersangka atau keluarganya.

Hakim menyatakan bahwa dalam perkara a quo, Termohon dalam cara memperoleh bukti-bukti tersebut disamping prosesnya harus sesuai prosedur juga harus berdasarkan ketentuan Undang-undang, sehingga seluruh tindakan yang dilakukan Termohon, khusus dalam perkara a quo dalam memperoleh bukti-bukti tersebut dengan cara yang sah, artinya dalam perkara a quo khusus untuk penyitaan perolehan bukti harus dengan Sprindik No. Sprin.Dik-56/01/07/2017 bukan Sprindik untuk perkara orang lain dan dalam perkara $a$ quo perolehan bukti penyitaan harus melalui proses penyidikan bukan proses penyelidikan karena dalam Undang-undang Nomor 30 Tahun 2002 tentang Komisi Pemberantasan Tindak Pidana Korupsi yang berhak melakukan penyitaan sesuai pasal tersebut di atas adalah penyidik.

Berdasarkan bukti-bukti tersebut, setelah diteliti dan dipelajari bahwa Termohon dalam perkara a quo telah melakukan tindakan-tindakan penyitaan berdasarkan sprindiksprindik atas nama Ir. Sugiharto, Irman dan Andi Narogong, sedangkan dalam perkara $a$ quo Surat Perintah Penyidikan baru dikeluarkan berdasarkan bukti T-24 Surat Perintah Penyitaan Nomor: Sprin.Sita58/01/07/2017 tanggal 17 Juli 2017, artinya Termohon dalam perkara a quo baru mempunyai kewenangan melakukan tindakan-tindakan penyitaansetelah tanggal 17 Juli 2017, sehingga menurut Hakim Praperadilan penyitaanpenyitaan yang dilakukan oleh Termohon harus dilakukan dalam tahap penyidikan.

Hakim berpendapat bahwa upaya pemberantasan korupsi bukan berarti tidak boleh mencari alat-alat bukti yang diperoleh dari alat-alat bukti lain yang perkaranya melibatkan beberapa orang, tidak boleh digunakan dalam perkara a quo, akan tetapi Termohon harus berpedoman pada prosedur dan tatacara yang benar sesuai dengan amanat Undang-undang tersebut dan di dalam perkara a quo sebagaimana telah dipertimbangkan di atas di antaranya adanya tindakan-tindakan dari Termohon yang akan mengambil bukti-bukti dalam perkara yang dilakukan secara bersama-sama (delik penyertaan), menurut Hakim Praperadilan tidak boleh diambil langsung menjadi bukti dalam perkara a quo, akan tetapi harus dilakukan sesuai dengan prosedur, dalam perkara a quo, apabila Termohon akan melakukan upaya paksa penyitaan harus dalam tahap penyidikan bukan dalam tahap penyelidikan dan prosedur lainnya yang harus ditempuh seperti dalam perkara a quo tahap 
penyidikan memeriksa ulang saksi-saksi, melakukan penyitaan, mencari dokumen yang mengambil dari perkara orang lain dalam delik penyertaan, tidak boleh langsung diambilalih.

Penetapan yang dilakukan oleh Termohon untuk menetapkan Pemohon sebagai Tersangka tidak didasarkan kepada prosedur dan tata cara ketentuan Undang-undang Nomor 30 Tahun 2002 tentang Komisi Pemberantasan Tindak Pidana Korupsi, KUHAP dan SOP KPK, maka penetapan Pemohon (Setya Novanto) sebagai Tersangka adalah tidak sah. Selanjutnya hakim praperadilan menimbang bahwa petitum No. 2 yang menyatakan batal/batal demi hukum dan tidak sah penetapan Tersangka terhadap Setya Novanto (Pemohon) yang dikeluarkan oleh Termohon berdasarkan Surat No. 310/23/07/2017 tanggal 18 Juli 2017, Perihal: Pemberitahuan Dimulainya Penyidikan dengan segala akibat hukumnya, oleh karena beralasan hukum maka patut untuk dikabulkan dengan perubahan redaksi. Petitum No. 3 Memerintahkan Termohon untuk menghentikan penyidikan terhadap Setya Novanto (Pemohon) berdasarkan Surat Perintah Penyidikan No. Sprin.Dik56/01/07/2017 tanggal 17 Juli 2017.

Pada Perkara Nomor: 04/Pid.Prap/2015/PN.Jak.Sel-Praperadilan Budi Gunawan yang menjadi pertimbangan Hakim secara garis besar antara lain adalah Objek permohonan praperadilan bukan kewenangan Hakim Praperadilan. Terkait langsung dengan permohonan Pemohon, karena "Penetapan Tersangka" merupakan bagian dari rangkaian tindakan Penyidik dalam proses penyidikan, maka lembaga hukum yang berwenang menguji dan menilai keabsahan "Penetapan Tersangka" adalah Lembaga Praperadilan. Sebagaimana telah dipertimbangkan bahwa segala tindakan Penyidik dalam proses pada tingkat penyidikan dan segala tindakan Penuntut Umum dalam proses pada tingkat penuntutan adalah merupakan tindakan upaya hukum paksa, karena telah menempatkan dan menggunakan label "Pro Justisia" pada setiap tindakan.

Petitum Permohonan Praperadilan tidak jelas (obscuur libel) dan saling bertentangan satu dengan yang lainnya. Dasar dan alasan hukum yang pertama dari Pemohon dalam mengajukan Permohonan Praperadilan ini adalah Termohon tidak mempunyai kewenangan untuk melakukan penyelidikan dan penyidikan Tindak Pidana Korupsi terhadap Pemohon. Pada Pasal 11 huruf a Undang-undang Nomor 30 tahun 2002 memberikan batasan mengenai orang-orang sebagai subjek hukum pelaku Tindak Pidana 
Korupsi yang menjadi kewenangan KPK untuk melakukan penyelidikan, penyidikan dan penuntutan Tindak Pidana Korupsi, yaitu :

1) Aparat penegak hukum;

2) Penyelenggara negara;

3) Orang lain yang ada kaitannya dengan tindak pidana korupsi yang dilakukan oleh aparat penegak hukum atau penyelenggara negara;

Undang-undang tidak memberikan penjelasan tentang pengertian dari "aparat penegak hukum" dan juga tidak menjelaskan tentang siapa saja yang termasuk aparat penegak hukum. Secara harfiah aparat penegak hukum dapat diartikan sebagai aparat negara yang diberi wewenang oleh Undang-undang melaksanakan tugas-tugas penegakan hukum.

Timbul pertanyaan, apakah Pemohon termasuk orang-orang sebagai subjek hukum pelaku Tindak Pidana Korupsi yang menjadi kewenangan KPK (Termohon) untuk melakukan penyelidikan, penyidikan dan penuntutan Tindak Pidana Korupsi. Pada bukti P14 tersebut di atas disebutkan pula bahwa jabatan Karo Binkar adalah suatu jabatan di bawah Deputi Kapolri Bidang Sumber Daya Manusia yang merupakan unsur pembantu pimpinan dan pelaksana staf, dan bukan aparat penegak hukum, karena jabatan Karo Binkar tidak memiliki kewenangan untuk melakukan tugas-tugas penegakan hukum.

Pada jawabannya Termohon telah menyatakan bahwa Termohon telah memaparkan bukti-bukti kualifikasi Pemohon sebagai Aparat Penegak Hukum atau Penyelenggara Negara, namun sepanjang pemeriksaan perkara ini bukti-bukti dimaksud tidak pernah diajukan oleh Termohon, sehingga Pengadilan Negeri berkesimpulan bahwa Termohon tidak dapat membuktikan bahwa Pemohon saatmenjabat sebagai Karo Binkar adalah sebagai Aparat Penegak Hukum dan atau Penyelenggara Negara sebagaimana dimaksud dalam ketentuan pasal 11 huruf a Undang-undang KPK.

Saat Pemohon menjabat sebagai Karo Binkar, masyarakat sama sekali tidak mengenal Pemohon, dan masyarakat baru mengenal Pemohon saat Pemohon ditetapkan sebagai calon tunggal Kapolri oleh Presiden Republik Indonesia, dan saat Pemohon ditetapkan sebagai Tersangka oleh Termohon, tepat sehari sebelum Pemohon mengikuti fit and proper test di DPR, sehingga kualifikasi mendapat perhatian yang meresahkan 
masyarakat sebagaimana dimaksud dalam pasal 11 huruf b Undang-undang KPK pun tidak terpenuhi.

Berdasarkan pertimbangan-pertimbangan tersebut, ternyata Pemohon bukanlah subjek hukum pelaku Tindak Pidana Korupsi yang menjadi kewenangan KPK (Termohon) untuk melakukan penyelidikan, penyidikan dan penuntutan Tindak Pidana Korupsi sebagaimana dimaksud dalam pasal 11 Undang-undang KPK, maka proses penyidikan yang dilakukan oleh Penyidik KPK terkait peristiwa pidana sebagaimana dimaksud dalam Penetapan Tersangka terhadap diri Pemohon sebagaimana dimaksud dalam Pasal 12 huruf a atau b, Pasal 5 ayat (2), Pasal 11 atau 12 B Undang-undang 31 Tahun1999 tentang Pemberantasan Tindak Pidana Korupsi Jo. Undang-undang 20 Tahun 2001 tentang Perubahan atas Undang-undang Nomor 31 Tahun 1999 tentang Pemberantasan Tindak Pidana Korupsi Jo. Pasal 55 ayat 1 ke-1 KUHP adalah tidak sah dan tidak berdasar atas hukum, dan oleh karenanya Penetapan aquo tidak mempunyai kekuatan mengikat.

Proses penyidikan yang dilakukan oleh Penyidik KPK berdasarkan Surat Perintah Penyidikan Nomor: Sprin.Dik-03/01/01/2015 tanggal 12 Januari 2015 telah dinyatakan tidak sah, maka Penetapan Tersangka atas diri Pemohon yang dilakukan oleh Termohon pun harus dinyatakan tidak sah.

Berdasarkan pertimbangan-pertimbangan tersebut di atas, maka Pengadilan Negeri menyatakan mengabulkan permohonan Pemohon untuk sebagian dan menolak selebihnya.Permohonan Praperadilan Pemohon dikabulkan untuk sebagian, maka sudah seharusnya biaya yang timbul dalam perkara ini dibebankan kepada Negara yang hingga kini ditaksir sebesar nihil.

\section{Putusan Hakim Praperadilan Terhadap Permohonan Praperadilan Penetapan Status Tersangka Pada Perkara Nomor: 97/Pid.Prap/2017/PN.Jkt.Sel. dan perkara no Nomor: 04/Pid.Prap/2015/PN.Jak.Sel}

Hakim Praperadilan dalam Putusan Nomor: 97/Pid.Prap/2017/PN.Jkt.Sel. mengabulkan permohonan Setya Novanto yang telah ditetapkan sebagai tersangka oleh Komisi Pemberantasan Korupsi (KPK) atas tindak pidana korupsi Pengadaan Paket Penerapan Kartu Tanda Penduduk Berbasis Nomor Induk Kependudukan Secara Nasional (KTP Elektronik) Tahun 2011 s/d 2012 pada Kementerian Dalam Negeri Republik Indonesia. Sesuai dengan putusan tersebut maka penetapan Tersangka terhadap Setya 
Novanto (Pemohon) yang dikeluarkan oleh Termohon berdasarkan Surat No. 310/23/07/2017 tanggal 18 Juli 2017 menjadi batal/batal demi hukum dan tidak sah.

Pada diri hakim hendaknya lahir, tumbuh dan berkembang adanya sikap/sifat kepuasan moral jika keputusan yang dibuatnya dapat menjadi tolak ukur untuk kasus yang sama, sebagai bahan referensi bagi kalangan teoritis dan praktisi hukum serta kepuasan nurani jika sampai dikuatkan dan tidak dibatalkan oleh Pengadilan Tinggi atau Mahkamah Agung jika perkara tersebut sampai ke tingkat banding atau kasasi. Hakim dalam membuat putusan harus memperhatikan segala aspek di dalamnya, yaitu mulai dari perlunya kehatihatian serta dihindari sedikit mungkin ketidakcermatan, baik bersifat formal maupun materiil sampai dengan adanya kecakapan teknik dalam membuatnya, (Lilik Mulyadi, $155: 2010)$

Menilai kebenaran keterangan para saksi maupun terdakwa, hakim harus memperhatikan persesuaian antara keterangan saksi satu dengan yang lain, persesuaian keterangan antara keterangan saksi dengan alat bukti lain, alasan yang mungkin dipergunakan oleh saksi untuk memberi keterangan yang tertentu, cara hidup dan kesusilaan saksi, serta segala sesuatu yang pada umumnya dapat mempengaruhi dapat tidaknya keterangan itu dipercaya.

Pada Perkara Nomor: 04/Pid.Prap/2015/PN.Jak.Sel dalam eksepsi menolak Eksepsi Termohon untuk seluruhnyandalam pokok perkara :

1. Mengabulkan Permohonan Pemohon Praperadilan untuk sebagian;

2. Menyatakan Surat Perintah Penyidikan Nomor: Sprin.Dik03/01/01/2015 tanggal 12 Januari 2015 yang menetapkan Pemohon sebagai Tersangka oleh Termohon terkait peristiwa pidana sebagaimana dimaksud dalam Pasal 12 huruf a atau b, Pasal 5 ayat (2), Pasal 11 atau 12 B Undang-undang Nomor 31 Tahun 1999 tentang Pemberantasan Tindak Pidana Korupsi jo. Undang-undang Nomor 20 Tahun 2001 tentang Perubahan atas Undang-undang Nomor 31 Tahun 1999 tentang Pemberantasan Tindak Pidana Korupsi jo. Pasal 55 ayat (1) ke-1 KUHP adalah tidak sah dan tidak berdasar atas hukum, dan oleh karenanya Penetapan aquo tidak mempunyai kekuatan mengikat;

3. Menyatakan Penyidikan yang dilaksanakan oleh Termohon terkait peristiwa pidana sebagaimana dimaksud dalam Penetapan Tersangka terhadap diri Pemohon sebagaimana dimaksud dalam Pasal 12 huruf a atau b, Pasal 5 ayat (2), Pasal 11 atau 12 
B Undang-undang Nomor 20 Tahun 2001 tentang Perubahan atas Undang-undang Nomor 31 Tahun 1999 tentang Pemberantasan Tindak Pidana Korupsi jo. Pasal 55 ayat 1 ke-1 KUHP adalah tidak sah dan tidak berdasar atas hukum, dan oleh karenanya Penyidikan aquo tidak mempunyai kekuatan mengikat;

4. Menyatakan Penetapan Tersangka atas diri Pemohon yang dilakukan oleh Termohon adalah tidak sah;

5. Menyatakan tidak sah segala keputusan atau penetapan yang dikeluarkan lebih lanjut oleh Termohon yang berkaitan dengan Penetapan Tersangka terhadap diri Pemohon oleh Termohon;

6. Membebankan biaya perkara kepada negara sebesar nihil;

7. Menolak Permohonan Pemohon Praperadilan selain dan selebihnya.

Dalam persidangan perkara praperadilan penamaan para pihak yang berperkara oleh KUHAP tidak diberikan secara jelas, bahkan dari beberapa pasal KUHAP yang mengatur tentang praperadilan, untuk pihak yang mengajukan pemeriksaan digunakan atau dicantumkan istilah secara tidak konsisten, misalnya dalam KUHAP pasal 79,80,81,82 ayat (1) huruf a,d,e tercantum istilah permintaan, yang berarti pihak yang mengajukan permintaan pemeriksaan praperadilan dinamakan sebagai "peminta", sedangkan dalam KUHAP pasal 82 ayat (1) huruf b tercantum istilah "pemohon" dan dalam KUHAP pasal 95 digunakan istilah "menuntut" dan "tuntutan". Akan tetapi dalam praktik, istilah yang pada umumnya lazim digunakan adalah istilah permohonan, pemohon dan termohon (H.M.A Kuffal, 224-255: 2008).

Dalam Putusan Nomor: 04/Pid.Prap/2015/PN.Jkt.Sel atau yang dikenal luas di masyarakat dengan kasus Budi Gunawan, yang menjadi pihak Pemohon adalah Komisaris Jenderal Polisi Drs. Budi Gunawan, SH., Msi., dan yang menjadi pihak Termohon adalah Komisi Pemberantasan Korupsi cq. Pimpinan KPK.Permohonan pemeriksaan praperadilan dapat diajukan oleh baik tersangka maupun keluarga atau kuasanya.Permohonan diajukan kepada Ketua Pengadilan Negeri dengan menyebutkan alasannya.

Dalam Putusan Nomor: 04/Pid.Prap/2015/PN.Jkt.Sel atau yang dikenal luas di masyarakat dengan kasus Budi Gunawan, permohonan pemeriksaan praperadilan diajukan oleh Budi Gunawan sendiri selaku Tersangka. Dalam hal ini, Budi Gunawan merupakan salah satu pihak yang berhak untuk mengajukan permohonan pemeriksaan 
praperadilan.Pemohon (tersangka, keluarga, pihak yang berkepentingan atau kuasa hukumnya) mengajukan permintaan/permohonan pemeriksaan praperadilan kepada Ketua Pengadilan Negeri yang berwenang yaitu Pengadilan Negeri yang daerah hukumnya meliputi domisili (kantor) aparat penegak hukum (penyidik/penuntut umum) yang diajukan sebagai Termohon, sesuai dengan ketentuan yang diatur dalam KUHAP pasal 79, 80 dan 81.

Dalam Putusan Nomor: 04/Pid.Prap/2015/PN.Jkt.Sel atau yang dikenal luas di masyarakat dengan kasus Budi Gunawan, domisili KPK selaku Termohon adalah di Jakarta Selatan dan daripada itu, Pengadilan Negeri tempat digelarnya pemeriksaan praperadilan adalah Pengadilan Negeri Jakarta Selatan. Sehingga telah sesuai dengan ketentuan yang diatur dalam pasal 79, 80 dan 81 KUHAP.Menurut Pasal 82 ayat (1) huruf c KUHAP ditegaskan bahwa pemeriksaan praperadilan dilakukan secara cepat (acara pemeriksaan cepat) dan selambat-lambatnya dalam waktu 7 (tujuh) hari hakim yang memeriksa perkara praperadilan harus sudah menjatuhkan putusannya.

Dalam Putusan Nomor: 04/Pid.Prap/2015/PN.Jkt.Sel atau yang dikenal luas di masyarakat dengan kasus Budi Gunawan, Surat Penetapan Ketua Pengadilan Negeri Jakarta Selatan tentang penunjukan Hakim tertanggal 26 Januari 2015, sementara putusan dijatuhkan pada hari Senin, tanggal 16 Februari 2015. Maka dapat diketahui bahwa pada kasus ini, acara pemeriksaan cepat tidak terwujud, karena putusan dijatuhkan lebih dari 7 (tujuh) hari. Pemeriksaan praperadilan dipimpin oleh hakim tunggal yang ditunjuk oleh ketua pengadilan negeri dan dibantu oleh seorang panitera (pasal 78 ayat (2) KUHAP).

Isi putusan praperadilan Pengadilan Negeri Jakarta Selatan yang mengabulkan permohonan praperadilan dari pemohon untuk sebagian, dianggap tidak berdasarkan hukum. Hal ini dikuatkan karena berdasarkan pengaturan pasal 77 KUHAP pada saat putusan dijatuhkan oleh Hakim tunggal, sah atau tidaknya penetapan status Tersangka bukan merupakan objek dari praperadilan. Alasan Hakim Sarpin dalam menafsirkan ketentuan dalam KUHAP tidak memiliki logika hukum, karena objek praperadilan berdasarkan Pasal 77 KUHAP bersifat limitatif dan tidak multitafsir. Oleh karena hal ini sangat terkait dengan kompetensi mengadili, maka menurut penulis putusan praperadilan $a$ quo cacat hukum. 
Walaupun terhadap putusan praperadilan dapat ditempuh upaya hukum luar biasa yakni peninjauan kembali (PK) demi kepentingan masyarakat umum yang hanya bisa diajukan oleh Jaksa Agung.Akan tetapi pada kasus praperadilan Budi Gunawan, Jaksa Agung bukanlah merupakan salah satu diantara para pihak. Maka untuk praperadilan $a$ quo, peninjauan kembali (PK) demi kepentingan masyarakat umum tidak dapat dilakukan. Kasus ini mengindikasikan bahwa lembaga praperadilan belum bekerja secara efektif sebagai alat kontrol dalam proses penegakan hukum dan keadilan.

\section{PENUTUP}

Pertimbangan Hakim terhadap permohonan praperadilan pada perkara Nomor: 97/Pid.Prap/2017/PN.Jkt.Sel. adalah alat bukti yang dijadikan sebagai dasar penetapan tersangka, setelah dipelajari dan diteliti tidak disertai dengan berita acara penyitaan. Pada perkara Nomor: 04/Pid.Prap/2015/PN.Jak.Se.1 yang menjadi pertimbangan Hakim secara garis besar antara lain adalah Objek permohonan praperadilan bukan kewenangan Hakim Praperadilan. Pertimbangan lain adalah Petitum Permohonan Praperadilan tidak jelas (obscuur libel) dan saling bertentangan satu dengan yang lainnya. Pemohon bukanlah subjek hukum pelaku Tindak Pidana Korupsi yang menjadi kewenangan KPK (Termohon) untuk melakukan penyelidikan, penyidikan dan penuntutan Tindak Pidana Korupsi sebagaimana dimaksud dalam pasal 11 Undang-undang KPK. Kedua; Putusan Hakim Praperadilan Terhadap Permohonan Praperadilan Penetapan Status Tersangka adalah pada perkara nomor: 97/Pid.Prap/2017/PN.Jkt.Sel. mengabulkan permohonan penetapan sebagai tersangka oleh Komisi Pemberantasan Korupsi (KPK) atas tindak pidana korupsi Pengadaan Paket Penerapan Kartu Tanda Penduduk Berbasis Nomor Induk Kependudukan Secara Nasional (KTP Elektronik) Tahun 2011 s/d 2012 pada Kementerian Dalam Negeri Republik Indonesia. Pada Perkara Nomor: 04/Pid.Prap/2015/PN.Jak.Sel dalam eksepsi menolak Eksepsi Termohon untuk seluruhnya dan Mengabulkan Permohonan Pemohon Praperadilan untuk sebagian;

\section{DAFTAR PUSTAKA}

Buku Teks:

Lilik Mulyadi.. Putusan Hakim dalam Hukum Acara Pidana, Teori, Praktik, Teknik Penyusunan dan Permasalahannya,Citra Aditya Bakti, Bandung 2010. 
H.M.A Kuffal, Penerapan KUHAP dalam Praktik Hukum, Universitas Muhammadiyah Malang Press, Malang, 2008.

\section{Pustaka Primer (Journal) :}

Riki Perdana Raya Waruwu, Praperadilan Pasca 4 Putusan MK, www.http.google.com.

\section{Peraturan Undang-Undang:}

Undang-undang Nomor 8 Tahun 1981 tentang Hukum Acara Pidana 